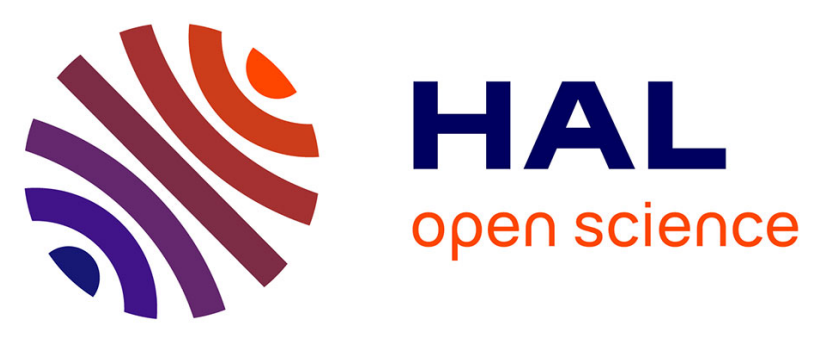

\title{
Pharmacokinetic and pharmacodynamic properties of an oral formulation of the histone deacetylase inhibitor Belinostat (PXD101)
}

\author{
N. L. Steele, J. A. Plumb, L. Vidal, J. Tjørnelund, P. Knoblauch, P. \\ Buhl-Jensen, R. Molife, R. Brown, J. S. de Bono, T. R. J. Evans
}

\section{To cite this version:}

N. L. Steele, J. A. Plumb, L. Vidal, J. Tjørnelund, P. Knoblauch, et al.. Pharmacokinetic and pharmacodynamic properties of an oral formulation of the histone deacetylase inhibitor Belinostat (PXD101). Cancer Chemotherapy and Pharmacology, 2010, 67 (6), pp.1273-1279. 10.1007/s00280010-1419-5 . hal-00615339

\section{HAL Id: hal-00615339 \\ https://hal.science/hal-00615339}

Submitted on 19 Aug 2011

HAL is a multi-disciplinary open access archive for the deposit and dissemination of scientific research documents, whether they are published or not. The documents may come from teaching and research institutions in France or abroad, or from public or private research centers.
L'archive ouverte pluridisciplinaire $\mathbf{H A L}$, est destinée au dépôt et à la diffusion de documents scientifiques de niveau recherche, publiés ou non, émanant des établissements d'enseignement et de recherche français ou étrangers, des laboratoires publics ou privés. 
Title:

Pharmacokinetic and pharmacodynamic properties of an oral formulation of the histone deacetylase inhibitor Belinostat (PXD101)

Authors:

N.L. Steele ${ }^{* 1,2}$, J.A. Plumb $*^{2}$, L.Vidal $^{3}$, J. Tjørnelund ${ }^{4}$,

P. Knoblauch ${ }^{4}$, P. Buhl-Jensen ${ }^{4}$, R. Brown ${ }^{2}$, J.S. de

Bono $^{3}$, T.R.J. Evans ${ }^{1,2}$.

*These authors contributed equally to this work

Addresses:

1. Beatson West of Scotland Cancer Centre

1053 Great Western Road

Glasgow G12 0YN

United Kingdom

2. Centre for Oncology and Applied Pharmacology

University of Glasgow

Garscube Estate

Switchback Road

Glasgow G61 1BD

United Kingdom

3. Royal Marsden Hospital

Downs Road

Sutton

Surrey SM2 5PT

United Kingdom

4. Topotarget

Symbion Science Park

Fruebjergvej 3, 2100

Copenhagen

Denmark 


\section{Correspondence to:}

Dr N.L. Steele

Beatson West of Scotland Cancer Centre

1053 Great Western Road

Glasgow G12 0YN

United Kingdom

Tel: $\quad$ +441413017000

Fax: $\quad$ +441413017061

e-mail: nicola.steele@ggc.scot.nhs.uk 


\section{ABSTRACT}

\section{Purpose}

The primary objective of this sub-study, undertaken as an extension to the previously reported phase I study, was to explore the feasibility, tolerability and pharmacokinetics (PK) of belinostat when administered by the oral route. Preliminary PD studies were also performed to enable comparison of the biologic effects of the oral and intravenous formulations.

\section{Patients and Methods}

Oral belinostat was administered in a range of doses and schedules (once, twice, or thrice daily), on either day 1 or days $1-5$, of the second or a subsequent treatment cycle in 15 patients who were included in the phase I trial of intravenous belinostat. Serial blood samples were collected for pharmacokinetic and pharmacodynamic (histone acetylation) analyses, and the results compared with corresponding analyses following intravenous administration.

\section{Results}

A total mean daily AUC of $2767 \pm 1453 \mathrm{ng} \mathrm{hr} / \mathrm{ml}(8.7 \pm 4.6 \mu \mathrm{M} \mathrm{hr})$ resulted from a dose of $1000 \mathrm{mg} / \mathrm{m}^{2}$ once daily (qd). There was no clear evidence of drug accumulation on twice daily dosing (bid) however a trend towards accumulation was apparent when belinostat was given three times daily (tid). Mean half life ( $\mathrm{T}^{1 / 2}$ ) of a single dose of $1000 \mathrm{mg} / \mathrm{m}^{2}$ was $1.5 \mathrm{hr}( \pm 0.3 \mathrm{hr})$ and peak levels were reached in an average of $1.9 \mathrm{hrs}( \pm 0.3 \mathrm{hr})$. The half life was found to be independent of dose, but a trend towards increasing half life following multiple dosing was observed. Histone H4 
hyperacetylation in PBMCs estimated after oral dosing was comparable to that achieved after intravenous administration.

\section{Conclusions}

High doses of oral belinostat, up to $1000 \mathrm{mg} / \mathrm{m}^{2}$ bid for 5 consecutive days, have been tolerated in this small study. An oral formulation could lead to enhanced drug exposure and, more importantly, prolonged effects on the intended drug target. Future trials are required to establish the optimal dose and schedule of oral administration of belinostat.

\section{Key Words:}

Histone deacetylase, Phase 1 trial, Pharmacokinetics, Pharmacodynamics, bioavailability 


\section{INTRODUCTION}

Deregulation of the balance between histone acetylation and deacetylation plays a role in the generation and suppression of neoplasia. The histone deacetylase (HDAC) enzymes catalyse the removal of an acetyl group from the terminal lysine residues of histone proteins, leading to more compact chromatin and repression of associated genes. Inhibitors of HDAC enzymes alter patterns of gene expression, induce cellular differentiation and promote cell cycle arrest and apoptosis [1]. Pharmacologic inhibition of histone deacetylation may therefore regulate gene expression patterns and, subsequently, cellular characteristics, making them attractive anti-cancer therapies. Histone deacetylase inhibitors (HDACi) are relatively selective for cancer cells, possibly due to their effects being limited to only a small number of genes [2]. In addition, acetylation of non-histone proteins e.g. p53 [3] and $\mathrm{Rb}$ [4] may play a role in the anti-tumour activity of these compounds.

Belinostat (PXD101) is a novel hydroxamic acid HDAC inhibitor with potent antiproliferative and HDAC inhibitory activity both in vitro and in vivo [5]. Inhibition of tumour growth by belinostat is associated with a marked increase in the level of acetylation of histone proteins [5]. We have previously reported the results of a phase I trial of belinostat administered as a 30-minute intravenous infusion on days $1-5$ of a 21-day cycle [6]. In this trial, belinostat was well-tolerated, exhibited dose-dependent pharmacodynamic (PD) effects, and had promising anti-tumour activity. The maximum tolerated dose of belinostat administered intravenously in this dose and schedule was $1000 \mathrm{mg} / \mathrm{m}^{2} /$ day [6]. 
However, pharmacodynamic effects of belinostat on histone acetylation were most marked in the first few hours following intravenous drug administration. Consequently, a protracted or continuous daily oral dosing schedule could be advantageous, allowing continual target inhibition. In addition, patient convenience and health economic benefits also favour an oral route of administration. Furthermore, the availability of both intravenous and oral routes of administration would allow greater flexibility to design combination regimens with other anti-cancer agents in subsequent clinical studies.

The primary objective of this sub-study, undertaken as an extension to the previously reported phase I study, was to explore the feasibility, tolerability and pharmacokinetics $(\mathrm{PK})$ of belinostat when administered by the oral route. Preliminary PD studies were also performed to enable comparison of the biologic effects of the oral and intravenous formulations.

\section{PATIENTS AND METHODS}

\section{Patient Eligibility}

This study was conducted as an extension to the phase 1 trial of intravenous belinostat which has previously been reported [6]. Eligible patients were those with histologic or cytologic confirmed advanced malignancy, refractory to standard therapy, or for whom no standard therapy existed. Other inclusion criteria included age $\geq 18$ years, ECOG performance status (PS) $\leq 2$ and estimated life expectancy of $\geq 3$ months. Adequate bone marrow, hepatic and renal function for trial entry was defined as: $\mathrm{Hb} \geq$ $9.0 \mathrm{~g} / \mathrm{dl}$, absolute neutrophil count $\geq 1.5 \times 10^{9} / 1$, platelets $\geq 100 \times 10^{9} / 1$, total bilirubin $\leq 1.5 \times$ upper limit of normal (ULN), AST and ALT $\leq 2.5 \times$ ULN (or $\leq 5 \times$ ULN if 
liver metastases were present), serum creatinine $\leq 1.5 \times$ ULN. Female patients of reproductive potential were required to have a negative pregnancy test.

Patients were excluded from the trial if they had received any anti-cancer therapy within the preceding 4 weeks. Continuation of bisphosphonates, LHRH agonists or corticosteroids was permitted provided dosing was stable before and during the trial. Other exclusions were co-existing illness likely to interfere with trial procedures, uncontrolled brain metastases, persistent neuropathy $\geq$ NCI-CTCAE grade 2 of any cause, pregnant or lactating women, and known HIV infection.

Amendments to the original trial protocol of intravenous belinostat, to allow oral administration using a variety of schedules, were approved by the Research Ethics Committees at both participating institutions. Specific written informed consent for the oral sub-study was obtained from each patient in addition to the consent previously obtained for the main trial of intravenous belinostat.

\section{Study Design}

All patients received belinostat as a 30-minute intravenous infusion daily on days 1-5 of a 21-day cycle. The starting dose was $150 \mathrm{mg} / \mathrm{m}^{2}$. Sequential cohorts of 3-6 patients were entered into one of the escalating dose levels. Dose escalation was in $100 \%$ increments until grade 2 toxicity was observed, at which point dose escalation was in $50 \%$ increments until grade 3 toxicity was seen, following which further dose increments would be of $33 \%$. 
Following the initiation of the phase I trial of intravenous belinostat, a limited preliminary study of oral drug administration was planned in patients already enrolled to the main trial. On the basis that pre-clinical data from dogs had demonstrated an oral bioavailability for belinostat of 30-35\% (Topotarget, personal communication), eligible patients with stable disease after 2 cycles of intravenous belinostat were given a single oral dose of belinostat on day 1 of cycle 3 . The dose administered was equal to the dose that had been tolerated when administered intravenously to the same patient. Following the single oral dose, all subsequent doses for this, and subsequent, cycles were administered intravenously. Following further amendments to the trial protocol belinostat was subsequently administered orally, at the same dose as administered intravenously, twice or three times daily to eligible patients on day 1 only of their second, or subsequent, cycle and then administered, again at the same dose as administered intravenously, in a further cohort of patients once daily on days 1-5 of the second or third cycle. All other doses in all subsequent cycles were administered intravenously.

Toxicities were assessed weekly and graded and reported according to NCI-CTCAE v3.0. Patient assessments for toxicity and anti-tumour activity were not influenced by participation in this sub-study of oral administration of belinostat. Dose limiting toxicity (DLT) was based on the toxicities observed in the first 21 day cycle of intravenous belinostat. However, patients participating in the oral dosing sub-study were observed for any toxicity in addition to those seen with intravenous treatment. 


\section{Drug Preparation and Administration}

Belinostat was supplied by Topotarget, Copenhagen, Denmark. Belinostat powder was formulated in standard gelatine capsules containing $250 \mathrm{mg}$ for oral administration. Patients were not required to fast prior to drug administration.

\section{Pharmacokinetic studies}

PK samples were taken from 14 of the 15 patients enrolled in the oral study. Samples of $5 \mathrm{~mL}$ of blood were collected at the following time-points: once daily dosing schedule - time 0 (before oral administration of belinostat) then at 5, 15, 30, 60 and 90 minutes and 2, 4, 6, 8, 10 and 24 hours after administration; twice daily dosing schedule - time 0 , then at 15, 30, 60 and 90 minutes and 2, 4, 6, 8 and 12 hours (immediately before the second oral dose) after administration, and at 2, 4, 6, 8 and 12 hours (prior to the next intravenous dose) after administration of the second oral dose; thrice daily dosing schedule - time 0, then at 15, 30, 60 and 90 minutes and 2, 4, 6 and 8 hours (immediately before the second dose) following the first dose, at 2, 4, 6 and 8 hours (prior to the third dose) following the second dose, and then at 8 hours (prior to the next intravenous dose) following the third dose.

Lithium heparinised blood samples were placed on ice then centrifuged at $4^{\circ} \mathrm{C}$. Two milliliter aliquots of plasma were stored at $-70^{\circ} \mathrm{C}$ until analysis. The concentration of belinostat in plasma was analysed by liquid chromatography with tandem mass spectrometry detection as previously described [6]. PK calculations were performed using a non-compartmental method (WinNonLin version 5.1.0, model 200). The area under the plasma concentration time curve (AUC) was calculated using the linear 
trapezoid method and uniform weighting, and the elimination half-life was calculated by the log-linear method.

\section{Pharmacodynamic Studies}

\section{Histone hyperacetylation in peripheral blood mononuclear cells}

Histone acetylation was evaluated by Western blotting for histone $\mathrm{H} 4$ on histones isolated from peripheral blood mononuclear cells (PBMCs). Samples for histone acetylation were taken at various time points after intravenous administration of belinostat in cycle 1 and after oral administration in cycle 2 . Blood samples $(6 \mathrm{ml})$ were collected in lithium heparin vacutainer tubes, placed on ice and processed immediately using a modification of the method described by Yoshida et al [7] and as previously described [6]. Densitometry was carried out on the resulting Western blots and the results were expressed relative to a control sample (histones extracted from A2780 ovarian cancer cell line treated for 1 hour with belinostat $0.2 \mu \mathrm{M})$. The same cell line standard was used in all blots. AUC for histone acetylation was calculated by non-compartmental analysis using WinNonLin Version 4.0 software (Pharsight, Mountain View, USA).

\section{RESULTS}

\section{Patient Characteristics}

A total of 46 patients were recruited into the phase 1 trial of belinostat, by intravenous administration, between October 2003 and February 2006 as previously reported [6]. Fifteen of these patients were also enrolled into this sub-study of oral belinostat between August 2004 and January 2006. Details of the oral dosing schedule for each 
patient are summarised in table 1. One patient received two schedules of oral belinostat in different treatment cycles. Baseline characteristics for these 15 patients are summarised in table 2.

\section{Toxicity Assessments}

There were no toxicities, in addition to those observed with the intravenous formulation, in any of the 15 patients who were treated in this sub-study with oral belinostat. The most frequent toxicities associated with the brief duration of the oral dosing schedules were nausea ( 2 patients), vomiting ( 2 patients), fatigue ( 2 patients) and decreased lymphocyte counts ( 3 patients). These were all mild and self-limiting. Nausea and vomiting tended to occur several hours after oral dosing compared with the intravenous administration treatment schedule in which nausea and vomiting tended to occur at the end of the 30-minute intravenous infusion.

\section{Pharmacokinetics}

The pharmacokinetic profile of oral belinostat was evaluated in 14 patients using a variety of dosing schedules and compared with the pharmacokinetic profile of belinostat by intravenous administration in the same patients. These results are summarised in table 3. The exposure following oral dosing of belinostat was variable but sufficient to achieve histone acetylation (Figure 2) and in a potentially therapeutic range based on observations in pre-clinical models [8-10]. Total mean daily AUC of $2767 \pm 1453 \mathrm{ng} \mathrm{hr} / \mathrm{ml}(8.7 \pm 4.6 \mu \mathrm{M} \mathrm{hr})$ resulted from a dose of $1000 \mathrm{mg} / \mathrm{m}^{2}$ once daily (qd). There was no clear evidence of drug accumulation on twice daily dosing (bid) however a trend towards accumulation was apparent when belinostat was given three times daily (tid). Mean half life (T1/2) of a single dose of $1000 \mathrm{mg} / \mathrm{m}^{2}$ was $1.5 \mathrm{hr}( \pm 0.3$ 
hr) and peak levels were reached in an average of $1.9 \mathrm{hrs}( \pm 0.3 \mathrm{hr})$. The half life was found to be independent of dose, but a trend towards increasing half life following multiple dosing was observed. Assessment of dose linearity was not performed due to the small number of patients in this sub-study combined with the large variation in clearance.

\section{Pharmacodynamic Studies}

\section{Histone $\mathrm{H} 4$ hyperacetylation in peripheral blood mononuclear cells}

Histone $\mathrm{H} 4$ acetylation levels following intravenous and oral administration of belinostat are shown in Figure 1. The pre-treatment level of histone acetylation was slightly higher in the group given oral belinostat. Histone acetylation increases rapidly after intravenous administration of belinostat (Tmax $77.1 \pm 20.3)$. The rate of increase is slower following oral administration (Tmax $210.0 \min \pm 46.8$ ) although increased levels are sustained for longer. For two patients samples were collected at 12 hours, immediately before a second oral dose was administered. At 12 hours the level of acetylation was above the baseline level and histone acetylation increased rapidly after the second oral dose. The AUC for histone acetylation measured over the first 6 hours is $272.2 \pm 14.9$ for intravenous and $276.6 \pm 16.0$ for oral administration $(n=7)$.

\section{Clinical Outcomes}

Objective response and survival for patients treated with intravenous belinostat have previously been reported [6]. It was not anticipated that these would have been influenced by oral dosing as each patient only had limited exposure to the oral formulation. Consequently there is no efficacy data from this preliminary sub-study. 


\section{DISCUSSION}

The preliminary data reported in this study are limited by the small sample size and the heterogenous dosing cohorts, particularly with the thrice daily schedule which was only administered to two patients. Nevertheless, these preliminary data provide support for the continued development of an oral formulation of the HDAC inhibitor belinostat. Oral belinostat was well tolerated at high doses and provides higher exposure (AUC) in plasma than other orally dosed HDAC inhibitors such as MS-275, vorinostat and MGCD0103 at their recommended doses or at their respective maximum tolerated doses [11-13]. A slight increase in the AUC of belinostat from day 1 to day 5 was observed $(\mathrm{qd}=26 \%$; bid $=17 \%)$, although it is unclear if this observation is due to drug accumulation. No significant accumulation was found following intravenous infusion of belinostat for 5 consecutive days [6]. Intake of food or fluid with the oral formulation was not controlled in this small study, and no preclinical food effect studies have been performed. Consequently, an effect of food on drug pharmacokinetics may have contributed to the variable and, in some cases, increased exposure similar to that reported for vorinostat [14] and MGD0103 [11].

The variability in clearance with oral belinostat is rather large. The coefficient of variation $(\mathrm{CV})$ for the clearance has been calculated for dose groups with more than two patients. $\mathrm{CV}$ is $62 \%(\mathrm{n}=11)$ for the $1000 \mathrm{mg} / \mathrm{m}^{2}$ dose level ( $\mathrm{qd}$ and bid cohorts) whereas CVs are 39\% (n=4), 45\% (n=5), and 71\% (n=3) for the 1500,1750 , and $2000 \mathrm{mg}$ groups, respectively. This indicates that dosing by body surface area does not eliminate variance in clearance for belinostat, similar to reported findings for MS275 [15]. The reason for the variation in clearance has not been identified in this small 
study but correction for the patients' surface area may not be required for oral dosing of belinostat

The mean apparent half-life ( $\left.\mathrm{t}^{1} / 2\right)$ of 1.9 hours following oral administration of 1000 $\mathrm{mg} / \mathrm{m}^{2}$ on day 1 and 1.7 hours on day 5 were longer than the mean apparent $\mathrm{t}^{1} / 2$ of 0.8 hours following intravenous administration of the oral-equivalent dose of belinostat. This suggests an absorption-rate limited drug disposition in the GI tract and possibly entero-hepatic re-circulation. This observation is supported by pre-clinical studies with radiolabelled belinostat in the rat. In the intact rat, $45 \%$ of an oral dose is excreted via urine compared to $20 \%$ in bile duct - cannulated rats. Influence of feeding conditions on absorption have been reported for other hydroxamate HDAC inhibitors including vorinostat [13] and MS-275 [11]

The effects of belinostat on histone acetylation were comparable for the two routes of administration suggesting that oral dosing is an effective route of administration (Figure 1). Levels of acetylation increase more rapidly after intravenous than after oral administration which is consistent with the drug pharmacokinetics where the Tmax is later following oral drug administration. The level of acetylation was very low in untreated patients but was higher in the pre-treatment sample taken from patients prior to oral dosing. This could be explained by the effects of previous cycles of treatment. For two patients, levels of histone $\mathrm{H} 4$ acetylation were measured following the second oral dose (Figure 2). Acetylation levels increased rapidly as seen after the first dose indicating that twice daily dosing has a more prolonged effect on the drug target. 
High doses of oral belinostat, up to $1000 \mathrm{mg} / \mathrm{m}^{2}$ bid for 5 consecutive days, have been tolerated in this small study. Preliminary indications of anti-tumour activity observed in the phase 1 trial of intravenous belinostat are encouraging and support further trials of this drug. An oral formulation could lead to enhanced drug exposure and, more importantly, prolonged effects on the intended drug target. A trial is ongoing to establish the optimal dose and schedule of oral administration of belinostat.

\section{ACKNOWLEDGEMENTS}

This study was supported by Topotarget, Copenhagen, Denmark. The investigators at both the study centres are supported by Cancer Research UK.

The investigators are grateful to the research teams at both study centres for their support of this study, and to the patients who agreed to participate in this study. 
Table 1. Oral belinostat doses and schedules

\begin{tabular}{|c|c|c|c|}
\hline Patient & $\begin{array}{l}\text { Dose Level } \\
\left(\mathrm{mg} / \mathrm{m}^{2} / \text { day }\right)\end{array}$ & $\begin{array}{l}\text { Actual Dose } \\
\text { (mg) }\end{array}$ & Oral dosing schedule \\
\hline 1 & 900 & 1250 & day 1 q.d \\
\hline 2 & 900 & 1500 & day 1 q.d \\
\hline $3 \mathrm{a}$ & 1000 & 1750 & day 1-5 q.d. \\
\hline $3 \mathrm{~b}$ & 1000 & 1750 & day 1 t.i.d. \\
\hline 4 & 1000 & 2000 & day 1-5 q.d \\
\hline 5 & 1000 & 1500 & day 1-5 q.d \\
\hline 6 & 1000 & 1500 & day 1 b.i.d. \\
\hline 7 & 1000 & 1750 & day 1 b.i.d. \\
\hline 8 & 1000 & 1750 & day 1 b.i.d. \\
\hline 9 & 1000 & 1750 & day 1 b.i.d. \\
\hline 10 & 1000 & 2000 & day 1 b.i.d. \\
\hline 11 & 1000 & 1750 & day $1-5$ b.i.d. \\
\hline 12 & 1000 & 2000 & day $1-5$ b.i.d. \\
\hline 13 & 1000 & 1500 & day 1-5 b.i.d. \\
\hline 14 & 1000 & 2000 & day 1 t.i.d \\
\hline 15 & 1200 & 2500 & day 1 q.d \\
\hline
\end{tabular}


Table 2. Patient Characteristics

\begin{tabular}{|lc|}
\hline \multicolumn{1}{|c|}{ Characteristic } & No. of patients \\
\hline Total & 15 \\
Age (years) & \\
Median & 57 \\
Range & $25-70$ \\
Sex & \\
Male & 8 \\
Female & 7 \\
ECOG Performance Status & \\
0 & 6 \\
1 & 9 \\
Tumour Type & \\
Colorectal & \\
Melanoma & 3 \\
Renal & 1 \\
Oesophago-gastric & 2 \\
Sarcoma & 1 \\
Ovary & 3 \\
Thymoma & 1 \\
Breast & 1 \\
Prostate cancer & 1 \\
NSCLC & 1 \\
& 1 \\
\hline
\end{tabular}


Table 3. Summary of Mean $( \pm$ SD) PK Parameters after Oral Administration of belinostat

\begin{tabular}{|c|c|c|c|c|c|c|c|c|c|c|}
\hline $\begin{array}{l}\text { Administration } \\
\text { Schedule (number of } \\
\text { pt) }\end{array}$ & $\begin{array}{l}\text { Dose } \\
(\mathrm{mg} / \mathrm{m} 2)\end{array}$ & Dose (mg) & $\begin{array}{l}\text { Cmax } \\
(\mathrm{ng} / \mathrm{mL})\end{array}$ & $\underset{(\mathrm{h})}{\operatorname{Tmax}}$ & $\begin{array}{l}\mathbf{T} 1 / 2 \\
\text { (h) }\end{array}$ & $\begin{array}{l}\mathbf{V z} \\
(\mathrm{L})\end{array}$ & $\begin{array}{l}\text { CL } \\
(\mathrm{L} / \mathrm{hr})\end{array}$ & $\begin{array}{l}\mathbf{A} \mathbf{U C}_{\mathbf{0 - t}} \\
\left(\mathrm{ng}^{*} \mathrm{hr} / \mathrm{mL}\right)\end{array}$ & $\begin{array}{l}\mathbf{A U C}_{\mathbf{0}-\infty} \\
\left(\mathrm{ng}{ }^{*} \mathrm{hr} / \mathrm{mL}\right)\end{array}$ & $\begin{array}{l}\mathbf{A} \mathbf{U} \mathbf{C}_{0-\mathrm{t} /} \\
\mathbf{A} \mathbf{U} \mathbf{C}_{\mathbf{0}-\infty}\end{array}$ \\
\hline $\begin{array}{l}\text { Single day, qd } \\
n=2\end{array}$ & 900 & $1375( \pm 177)$ & $\begin{array}{l}3229 \\
( \pm 1376)\end{array}$ & $\begin{array}{l}1.7 \\
( \pm 0.2)\end{array}$ & $\begin{array}{l}0.9 \\
( \pm 0.2)\end{array}$ & $\begin{array}{l}293 \\
( \pm 50)\end{array}$ & $\begin{array}{l}219 \\
( \pm 1)\end{array}$ & $\begin{array}{l}6266 \\
( \pm 862)\end{array}$ & $\begin{array}{l}6292 \\
( \pm 862)\end{array}$ & 1.00 \\
\hline $\begin{array}{l}\text { Five days, qd } \\
\text { Day } 1 \\
n=3\end{array}$ & 1000 & $\begin{array}{l}1750 \\
( \pm 250)\end{array}$ & $681( \pm 350)$ & $\begin{array}{l}1.9 \\
( \pm 0.3)\end{array}$ & $\begin{array}{l}1.5 \\
( \pm 0.3)\end{array}$ & $\begin{array}{l}1511 \\
( \pm 592)\end{array}$ & $\begin{array}{l}767 \\
( \pm 441)\end{array}$ & $\begin{array}{l}2695 \\
( \pm 1461)\end{array}$ & $\begin{array}{l}2767 \\
( \pm 1453)\end{array}$ & 0.97 \\
\hline $\begin{array}{l}\text { Five days, qd } \\
\text { Day } 5 \\
n=3\end{array}$ & 1000 & $\begin{array}{l}1750 \\
( \pm 250)\end{array}$ & $\begin{array}{l}1317 \\
( \pm 736)\end{array}$ & $\begin{array}{l}2.0 \\
( \pm 0.1)\end{array}$ & $\begin{array}{l}1.7 \\
( \pm 1.1)\end{array}$ & $\begin{array}{l}1416 \\
( \pm 1213)\end{array}$ & $\begin{array}{l}516 \\
( \pm 134)\end{array}$ & $\begin{array}{l}3016 \\
( \pm 573)\end{array}$ & $3476( \pm 648)$ & 0.87 \\
\hline $\begin{array}{l}\text { Single day, qd } \\
\mathrm{n}=1\end{array}$ & 1200 & 2500 & 1729 & 1.3 & 1.4 & 719 & 348 & 7139 & 7174 & 1.00 \\
\hline $\begin{array}{l}\text { Single day, bid, am } \\
\mathrm{n}=7\end{array}$ & 1000 & $1750( \pm 189)$ & $\begin{array}{l}1447 \\
( \pm 782)\end{array}$ & $\begin{array}{l}2.1 \\
( \pm 1.3)\end{array}$ & $\begin{array}{l}1.6 \\
( \pm 0.4)\end{array}$ & $\begin{array}{l}1104 \\
( \pm 691)\end{array}$ & $\begin{array}{l}492 \\
( \pm 308)\end{array}$ & $\begin{array}{l}4187 \\
( \pm 1552)\end{array}$ & $4357( \pm 1636)$ & 0.96 \\
\hline $\begin{array}{l}\text { Single day, bid, } \mathrm{pm}^{*} \\
\mathrm{n}=6\end{array}$ & 1000 & $1792( \pm 188)$ & $817( \pm 299)$ & $\begin{array}{l}1.5 \\
( \pm 0.9)\end{array}$ & $\begin{array}{l}2.6 \\
( \pm 1.6)\end{array}$ & $\begin{array}{l}1356 \\
( \pm 736)\end{array}$ & $374( \pm 65)$ & $4011( \pm 1278)$ & $4706( \pm 711)$ & 0.85 \\
\hline $\begin{array}{l}\text { Five days, bid } \\
a m^{*}(n=3)\end{array}$ & 1000 & $1917( \pm 144)$ & $1054( \pm 663)$ & $\begin{array}{l}1.2 \\
( \pm 0.6)\end{array}$ & $\begin{array}{l}3.4 \\
(0.4)\end{array}$ & $\begin{array}{l}2053 \\
( \pm 1180)\end{array}$ & $\begin{array}{l}410 \\
( \pm 198)\end{array}$ & $3990( \pm 2270)$ & $5116( \pm 2732)$ & 0.78 \\
\hline $\begin{array}{l}\text { Single day, tid } \\
\mathrm{n}=21^{\text {st }} \text { dose* }^{*}\end{array}$ & 1000 & $1875( \pm 177)$ & $\begin{array}{l}1227 \\
( \pm 780)\end{array}$ & $\begin{array}{l}1.0 \\
( \pm 0.1)\end{array}$ & 2.0 & 1077 & 369 & $3688( \pm 1082)$ & 4748 & 0.78 \\
\hline $\begin{array}{l}\text { Single day, tid } \\
n=22^{\text {nd }} \text { dose }\end{array}$ & 1000 & $\begin{array}{l}1875 \\
( \pm 177)\end{array}$ & $1103( \pm 74)$ & $\begin{array}{l}3.1 \\
( \pm 1.5)\end{array}$ & $\begin{array}{l}2.6( \pm \\
0.8)\end{array}$ & $\begin{array}{l}1515 \\
( \pm 979)\end{array}$ & $\begin{array}{l}378 \\
( \pm 138)\end{array}$ & $\begin{array}{l}4557 \\
( \pm 1642)\end{array}$ & $5219( \pm 1432)$ & 0.87 \\
\hline $\begin{array}{l}\text { Single day, tid } \\
n=23^{\text {rd }} \text { dose }\end{array}$ & 1000 & $\begin{array}{l}1875 \\
( \pm 177)\end{array}$ & $974( \pm 485)$ & $\begin{array}{l}2.1 \\
\pm(0.0)\end{array}$ & $\begin{array}{l}3.0 \\
( \pm 0.6)\end{array}$ & $\begin{array}{l}1640 \\
( \pm 782)\end{array}$ & $\begin{array}{l}370 \\
( \pm 104)\end{array}$ & $4327( \pm 1876)$ & $5360( \pm 1984)$ & 0.81 \\
\hline
\end{tabular}

*Data not sufficient for calculation of $\mathrm{T} 1 / 2, \mathrm{AUC} 0-\infty, \mathrm{Vz}$ and $\mathrm{Cl}$ for one $\mathrm{pt}$ 


\section{REFERENCES}

1. Marks PA, Richon VM, Rifkind RA (2000). Histone deacetylase inhibitors: inducers of differentiation or apoptosis of transformed cells. J Natl Cancer Inst 92: $1210-1216$

2. Van Lint C, Emiliani S, Verdin E (1996). The expression of a small fraction of cellular genes is changed in response to histone hyperacetylation. Gene Express 5: 245-253.

3. Gu W, Roeder RG (1997). Activation of p53 sequence-specific DNA binding by acetylation of the p53 C-terminal domain. Cell 90: 595-606.

4. Chan HM, Krstic-Demonacos M, Smith L et al (2001). Acetylation control of the retinoblastoma tumour-suppressor protein. Nat Cell Biol 3: 667-674.

5. Plumb JA, Finn PW, Williams RJ, et al (2003). Pharmacodynamic response and inhibition of growth of human tumor xenografts by the novel histone deacetylase inhibitor PXD101. Mol Cancer Ther 2: 721-728.

6. Steele NL, Plumb JA, Vidal L et al (2008). A phase 1 pharmacokinetic and pharmacodynamic study of the histone deacetylase inhibitor belinostat in patients with advanced solid tumors. Clin Cancer Res 14: 804-810.

7. Yoshida M, Kijima M, Akita M, Beppu T (1990). Potent and specific inhibition of mammalian histone deacetylase both in vivo and in vitro by trichostatin A. J Biol Chem 265: 17174-17179.

8. Tumber A, Collins LS, Petersen KD, et al (2007). The histone deacetylase inhibitor PXD101 synergises with 5-Fluorouracil to inhibit colon cancer cell growth in vitro and in vivo. Cancer Chemother Pharmacol 60: 275-283. 
9. Qian X, LaRochelle WJ, Ara G, et al (2006). Activity of PXD101, a histone deacetylase inhibitor, in preclinical ovarian cancer studies. Mol Cancer Ther 5: 2086-2095.

10. Qian X, Ara G, Mills E, et al (2008). Activity of the histone deacetylase inhibitor belinostat (PXD101) in preclinical models of prostate cancer. Int $\mathrm{J}$ Cancer 122: $1400-1410$.

11. Siu LL, Pili R, Duran I et al (2008). Phase I study of MGCD0103 given as a three-times-per-week oral dose in patients with advanced solid tumors. J Clin Oncol 2008: 1940-1947.

12. Ryan QC, Headlee D, Acharya M et al (2005). Phase I and pharmacokinetic study of MS-275, a histone deacetylase inhibitor, in patients with advanced and refractory solid tumors or lymphoma. J Clin Oncol 23: 3912-3922.

13. Kelly WK, O'Connor OA, Krug LM et al (2005). Phase I study of an oral histone deacetylase inhibitor, suberoylanilide hydroxamic acid, in patients with advanced cancer. J Clin Oncol 23: 3923-3931.

14. Rubin EH, Agrawal NG, Friedman EJ et al (2006). A study to determine the effects of food and multiple dosing on the pharmacokinetics of vorinostat given orally to patients with advanced cancer. Clin Cancer Res 12: 7039-7045.

15. Acharya MR, Karp JE, Sausville EA et al (2006). Factors affecting the pharmacokinetic profile of MS-275, a novel histone deacetylase inhibitor, in patients with cancer. Invest New Drugs 24: 367-375. 


\section{Figure Legends}

Fig 1 Upper Figure: Plasma concentrations following intravenous administration of belinostat $(\bullet, n=7)$ and subsequent oral administration of belinostat to the same patients (o);

Lower Figure: Histone $\mathrm{H} 4$ acetylation levels in PBMCs taken at various times following intravenous administration of belinostat $(\bullet, n=7)$ and subsequent oral administration of belinostat to the same patients (o).

Fig 2 Plasma concentrations (open symbols) and histone H4 acetylation levels (closed symbols) in two patients following oral administration of belinostat at $\mathrm{t}=0$ and again at $\mathrm{t}=720 \mathrm{~min}$. 

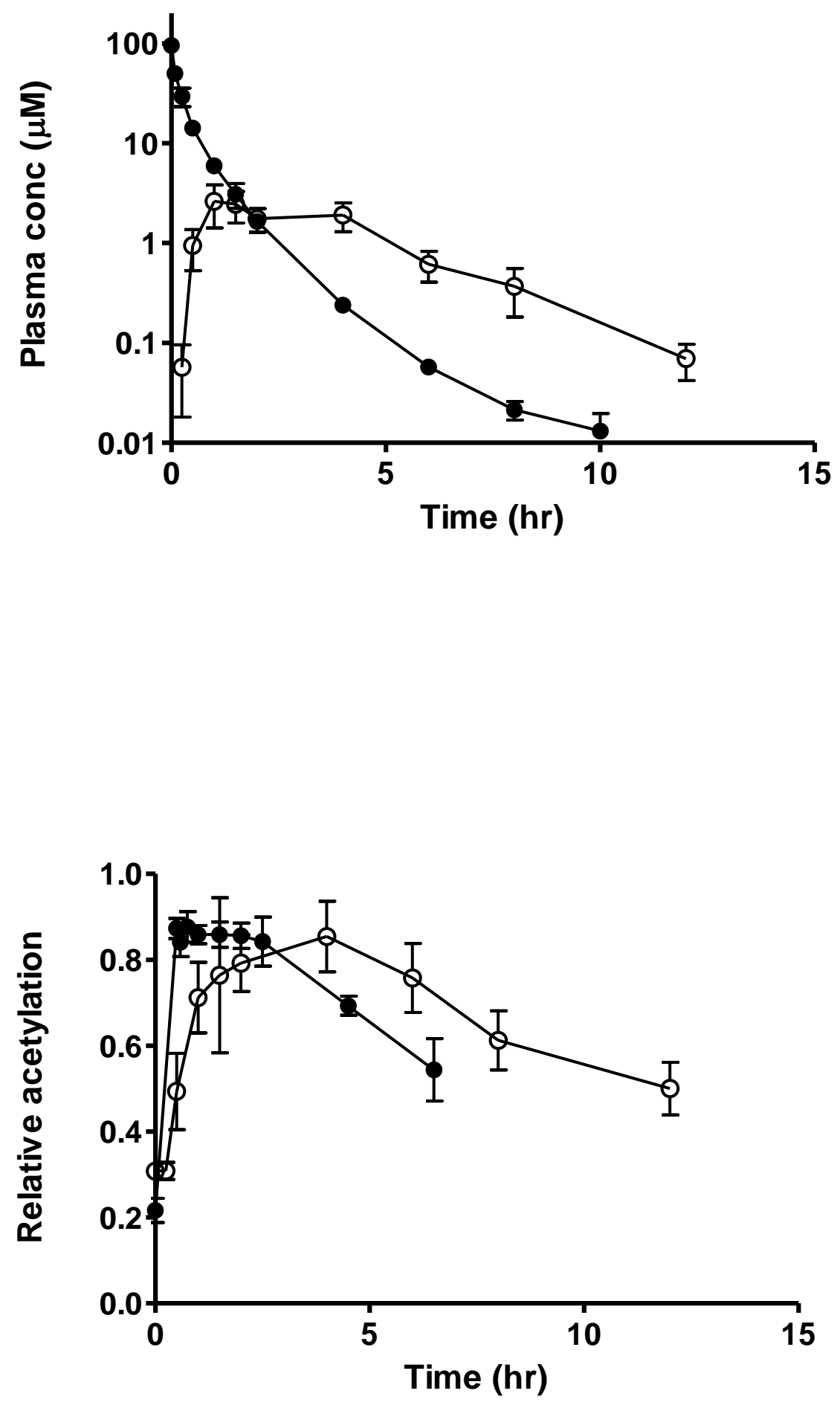


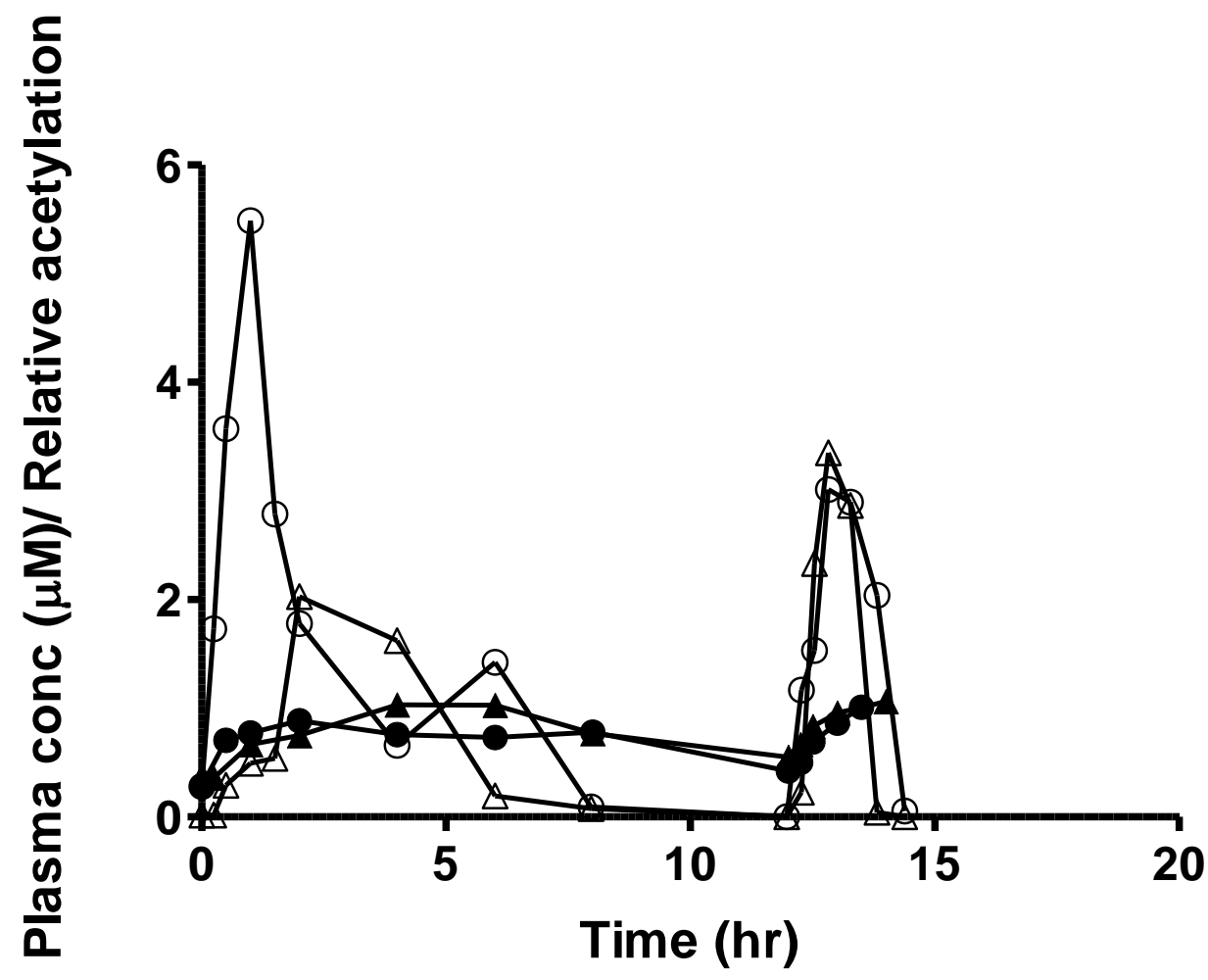

